\title{
Evsel Katı Atık Toplama ve Taşıma İşkolunda Çalışanların İş Sağlığı ve Güvenliği Koşullarının Değerlendirilmesi, Ankara-Yenimahalle Örneği
}

\author{
Occupational Health and Safety Conditions of Employees Working in the Domestic Waste \\ Collection and Transportation Business Field, Case of Ankara-Yenimahalle
}

\author{
Leyla Merve ÖZER ${ }^{1}$ (i) Orhan GÖKYAY $^{2}$ (i) \\ ${ }^{1}$ Marmara Üniversitesi, Işs Güvenliği Anabilim dal, İş Güvenliği Programı, İstanbul, TÜRKIYYE \\ ${ }^{2}$ Marmara Üniversitesi, Çevre Mühendisliği Bölümü, 34722, Kadıköy/İstanbul, TÜRKIYYE
}

$\ddot{O} z$

Evsel katı atık başka bir deyişle çöp, sadece çevre kirliliği anlamında ilgilenilen bir olgu değildir. Çöp genel kapsamıyla toplama, taşıma, ayrıştırma ve depolama gibi çeşitli aşamalara sahip bir süreçtir. Bu sebeple evsel katı atık alanında çalışanlar iş sağlığı ve güvenliği açısından birtakım risklerle karşılaşmaktadır. Karşılaşılan riskler detaylı şekilde araştırıldıktan sonra gerekli önlemler alınarak atılacak adımlar belirlenmelidir. Atık bilinci Türkiye'de yeteri kadar gelişmemiş̧ir. Çöpü mümkün olduğunca kaynağında ayırmak bu bilincin gelişmesindeki en önemli faktördür. Kazanılan atık bilinciyle birlikte çöpü kaynağında ayırmanın katı atıkları toplamak ve taşımak için yapılan masrafları azaltmasıyla birlikte evsel katı atık toplama ve taşıma işkolunda çalışanların sıklıkla karşılaştığı risk etmenlerinin de ortadan kalkmasına yardımcı olacağı düşünülmektedir. Geçmiş araştırmalar, bu işkolunda çalışanların önemli bir kısmının sağlık ve güvenlik problemleri ile devamlı olarak karşılaştıklarını göstermektedir. Evsel katı atık toplama ve taşıma işkolunda çalışanların iş sağlığı ve güvenliği koşullarının değerlendirilmesi amaçlanan bu çalışmada anket yöntemi kullanılmıştır. Anket sonuçlarına göre veri analizleri yapılıp hipotez testleri uygulanmış ve bu işkolunda çalışan işçilerde çalışma süreleri, eğitim düzeyleri, yaş grupları, yaralanma ve/veya hastalık geçirme durumları, teknik eğitim almış olmak ve almamış olmak durumları ve güvenlik önlemlerinin alınıyor ve alınmıyor olması durumlarına göre tehlike etmenleriyle karşılaşma sıklığı hakkında çeşitli sonuçlar çıkartılmış ve yorumlanmıştır.

Anahtar Kelimeler: Evsel katı atık, Atık bilinci, Belediye, İş sağlığı ve güvenliği

\begin{abstract}
Domestic solid waste which means garbage is not a fact that just concerned with the field of environment pollution. This sector has several phases like collection, transportation, sorting and storage. Employees can encounter with some serious risks in the field of occupational health and safety. Investigations should be done carefully and necessary precautions should be taken for all these risks. Awareness for waste is not developed sufficiently in Turkey. The separation of garbage at the source can be reduce costs to transport and dispose of solid wastes, and also be eliminate many risk factors people who work at the domestic solid waste collection and transport business. Field researches in this area show that employees are faced with serious health and security problems. In this study which is conducted to evaluate the occupational health and safety conditions of employees working in the domestic waste collection and transportation business field, firstly general information about the subject was given. According to the survey results, data analyses were carried out and hypothesis tests were applied in domestic solid waste collection and transportation field for variables like working time of workers, education levels, age groups, injury and/or disease status, taking or not taking technical training and taking or not taking safety precautions. Various conclusions have been drawn and interpreted about the frequency of encounters with hazard factors.
\end{abstract}

Keywords: Domestic solid waste, Waste awareness, Municipality, Occupational health and safety

\section{GIIRIŞ VE AMAÇ}

Katı atık, son kullanma tarihi geçmiş, kullanıcı tarafından istenmeyen ve üreticinin kullanamayacağı durumdaki, canlıların yaşadığı çevreden uzak tutulması gereken maddelerdir. Evsel katı atık diğer bir deyişle çöp adı üzerinde büyük bir kısmı evlerden atılan ve genellikle tehlikeli olmayan atıklardır. Katı atıkların kontrolü yönetmeliğine göre ilaç, pil, lastik, akü ve büyük hacimli ev eşyalarını evsel katıklarla atmak yasaklanmıştır [1].

Hızlı nüfus artı̧̧, göç ve çarpık kentleşmenin sonuçlarından biri olarak kentlerde katı atık kaynaklı sorunlar ortaya çıkmaktadır. Türkiye'de Katı atıkların toplanması, ayrıştırılması ve bertaraf edilmesi gibi katı atıkların yönetimi belediyelerin görev alanı içine girmektedir. Konu hakkındaki yönetmeliğe göre, evsel katı atık tanımı yapılmış ve bu tanımı kapsayan atıklar belirtilmiş olsa da Türkiye'deki atık bilinci yeteri kadar gelişmemiş olduğu için atılan çöplerin içerisinde tehlikeli olabilecek atıkların mevcudiyeti bilinmektedir. Dünyadaki çöp toplama sistemlerinden 
vakum teknolojisiyle çöp toplama ve tam otomatik çöp toplama sistemi, çöpün insan gücüyle toplanması ve taşınmasını ortadan kaldırdığı için çalışanların iş sağlığı ve güvenliği açısından karşılaşabilecekleri fiziksel, kimyasal, biyolojik ve ergonomik tehlike faktörlerini de ortadan kaldırmaktadır. Türkiye'de, dünyada kullanılmakta olan vakum teknolojisiyle çöp toplama ve tam otomatik çöp toplama sistemlerine geçen bir belediye henüz bulunmamaktadır. Ankara'nın iki en büyük belediyesi olan Yenimahalle ve Çankaya Belediyelerinin kullandığı yeraltı çöp toplama sistemini (daldırmalı çöp konteyner sistemi) yavaş yavaş diğer ilçe belediyeleri de kullanmaya başlamıştır. Bu yeni sistemin en büyük faydalarından biri işçilerin çöpleri insan gücüyle toplamadıkları ve taşımadıkları için ağır yük kaldırma tehlikelerinin ortadan kalkmasıdır. Diğer bir faydası ise işçilerin çöpe teması olmaması sonucunda kesilme ve delinme, solunum ve enfeksiyon hastalıkları tehlikeleri ortadan kalkacaktır. Türkiye'de atık bilinci gelişmediği sürece bu işkolunda çalışanların karşılaştığı tehlike ve riskler mevcut olup artmaya devam edecektir. Dolayısıyla bu çalışmada anket yöntemi kullanılarak Ankara'nın Yenimahalle belediyesi bünyesinde evsel katı atık toplama ve taşıma işkolunda çalışan temizlik işçilerinin iş sağlığı ve güvenliği koşullarının değerlendirilmesi amaçlanmıştır. Anket sonuçlarına göre hipotez testleri uygulanarak çeşitli sonuçlar çıkartılmış ve yorumlanmıştır.

\section{MATERYAL VE YÖNTEMLER}

Bu çalışma kapsamında Ankara'nın ikinci en büyük nüfuslu Yenimahalle ilçesinin evsel katı atık toplama ve taşıma işini yapan belediye ve taşeron firma bünyesinde saha çalışması yapılmıştır. Yenimahalle belediyesinde çalışanların başına gelmiş ve kayıtları tutulmuş olan iş kazaları ve meslek hastalıkları incelenip makalede sunulmuştur. Yenimahalle ilçesi temizlik işleri müdürlüğü bünyesinde çalışanlara yönelik anket çalışması yapılmıştır. Ankette işçilerin yaşları, çalışma süreleri, eğitim seviyeleri, son zamanlarda geçirdikleri yaralanmalar ve/veya hastalıklar ve kişisel koruyucu donanım kullanımı ile ilgili değerlendirme soruları sorulmuştur. Elde edilen anket verileri ve hipotez testleri sonuçlarına dayanılarak çeşitli analizler yapılmıştır.

Çalışmada 6 adet farklı hipotez testi yapılmıştır. Ankete katılan toplam kişi sayısı esas alınarak aritmetik ortalama ile hipotez belirlenmesinde kullanilacak olan ortalama kişi sayıları hesaplanmıştır. Toplamda 67 kişiye uygulanan bu anket sonucunda ilk dört hipotez testi için ikiye ayrılan gruplardaki insan sayısı belirlenip daha sonra o gruplar içerisinde tehlike etmenleriyle karşılaşan ortalama insan sayısı hesaplanmıştır. Son iki hipotez testi içinse sayıları ayrılan ikişerli gruplarda yaralanma ve/veya hastalık geçiren ortalama insan sayısı hesaplanmıştır. Her bir test için ortalama kişi sayısı hesabından sonra Excel'de standart sapmalar hesaplanmıştır.
Varyans analizi (F testi) kısmında varyansların homojenlik gösterip göstermediği belirlenmiştir. Bu teste göre $F_{\text {hesap }}$ belirtilen formül ile $F_{\text {tablo }}$ ise Excel'de FTERS formülü ile hesaplanmıştır.

$$
F_{\text {hesap }}=S_{\text {max }}^{2} \div S_{\text {min }}^{2}
$$

F testi sonucunda $F_{\text {hesap }}$ değeri $F_{\text {tablo }}$ değerinden küçük veya eşitse varyansların homojen olduğu kararına varılır. F testi sonucunda $F_{\text {hesap }}$ değeri $F_{\text {tablo }}$ değerinden büyükse varyansların homojen olmadığ 1 kararına varılır.

Hipotezlerin belirlenmesi kısmında $T_{\text {hesap }}$ belirtilen formülle, $T_{\text {tablo }}$ ise Excel'de TTERS formülü ile hesaplanmıştır. X değeri ortalama kişi sayısını, S değeri standart sapmayı, $\mathrm{N}$ değer ise kişi sayısını göstermektedir.

$H_{0}$ : Skor ortalamaları arasında fark yoktur. $\left(\mu_{1}=\mu_{2}\right)$ $H_{1}$ : Skor ortalamaları arasında fark vardır. $\left(\mu_{1} \neq \mu_{2}\right)$

$$
\begin{gathered}
S_{o}^{2}=\frac{\left(n_{1}-1\right) S_{1}^{2}+\left(n_{2}-1\right) S_{2}^{2}}{\left(n_{1}+n_{2}\right)-2} \\
T_{\text {hesap }}=\frac{\overline{X_{1}-X_{2}}}{\sqrt{\frac{S_{o}^{2}}{n_{1}}+\frac{S_{o}^{2}}{n_{2}}}}
\end{gathered}
$$

$T_{\text {hesap }}$ değeri $T_{\text {tablo değerinden küçük veya eşitse } H_{0}}$ hipotezi kabul edilip ortalamalar arasında fark olmadığ 1 sonucuna varılır.

$T_{\text {hesap }}$ değeri $T_{\text {tablo }}$ değerinden büyükse $H_{1}$ hipotezi kabul edilip ortalamalar arasında fark olduğu sonucuna varılır [4].

\section{BULGULAR VE TARTIŞMA}

\section{1. Çalışanlara Yönelik Anket Çalışması Veri Analizleri}

Toplam 67 çalışana anket uygulaması yapılmış ve anket uygulanan 67 çalışanın 64'ü erkek, 3'ü ise kadın çalışan, 35'i ilkokul, 14'ü ortaokul, 10'u lise ve 8'i üniversite mezunu olduğu belirlenmiştir. $\mathrm{Bu}$ kişiler arasında 1'i kırık ve çatlak, 7'si kesilme ve delinme, 6'sı ezilme yaralanmalarını geçirmiştir. Yine anket uygulanan 67 çalışanın 6'sı cilt ve alerjik hastalık, 3'ü solunum hastalığı ve 5 'i anket doldurulurken belirtilmemiş diğer yaralanma ve hastalıkları geçirmiştir. Yaralanma ve hastalık geçirmeyen toplam 43 kişi vardır. Çalışanların maruz kaldığı tehlike etmenleri gürültü, titreşim, ağır yük kaldırma, egzoz gazı ve diğer gazlar, kesici ve delici aletler ve haşere ve hayvanlardır. $\mathrm{Bu}$ çalışma sırasında ortaya çıkan çalışanların maruz kaldığı tehlike etmenleri ve dağılımları Şekil 1 ve Şekil 2'de verilmiştir. 


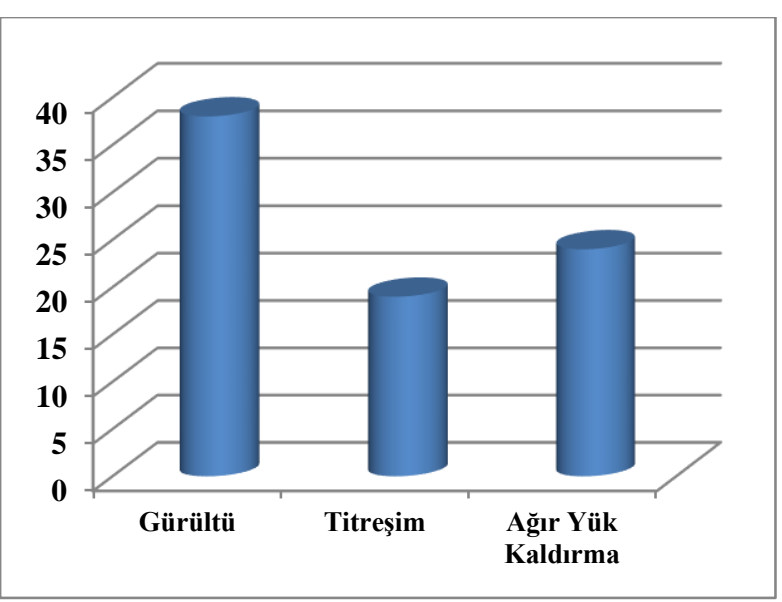

Şekil 1. Çalışanların maruz kaldığı tehlike etmenleri

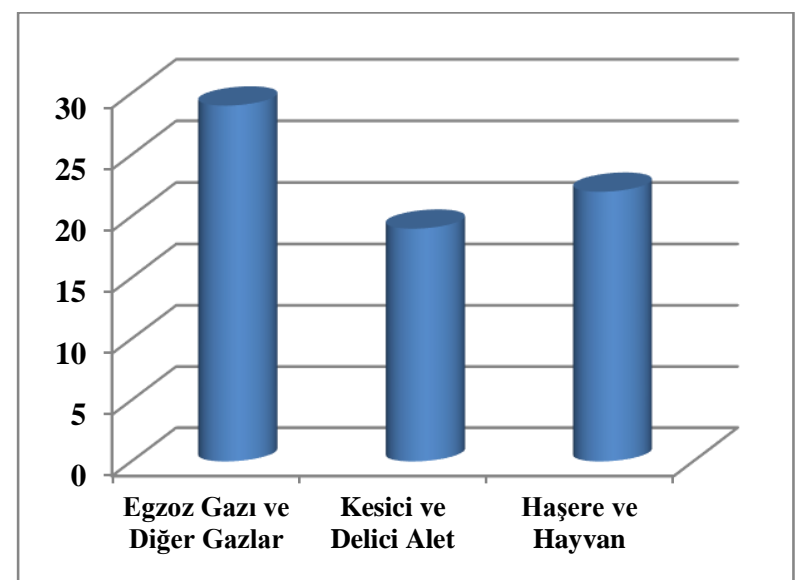

Şekil 2. Çalışanların maruz kaldığı tehlike etmenleri

Şekil 1 ve 2'de görüldüğü gibi anket uygulanan 67 çalışanın 38'i gürültüye, 19'u titreşime, 24'ü ağır yük kaldırmaya, 29'u egzoz gazı ve diğer gazlara, 19'u kesici ve delici alete ve 22 'si haşere ve hayvanlara maruz kaldığını belirtmiştir.

\subsection{Hipotez Testleri}

Yenimahalle Belediyesi temizlik işçilerine yapılan anket verileri 1şı̆̆ında bazı hipotez testleri uygulanmıştır. İlk dört hipotez testi ile tehlike etmenleriyle karşılaşma sıklığı skoru değişkeni yönünden yaş grupları, eğitim düzeyleri, çalışma süreleri ve yaralanma ve/veya hastalık geçirip geçirmeme durumları farklı grupların ortalamaları karşılaştırılıp ortalamalar arasında fark olup olmadığı gözlemlenmiştir. Son iki hipotez testi ile de yaralanma ve/veya hastalık geçirme sıklığı skoru yönünden teknik eğitim alınıp alınmaması ve güvenlik önlemlerinin alınıp alınmaması durumları farklı grupların ortalamaları karşılaştırılıp ortalamalar arasında fark olup olmadığı gözlemlenmiştir.

1. Yenimahalle Belediyesi temizlik işçilerine uygulanan anket sonucuna göre tehlike etmenleriyle karşılaşma sıklığı skoru değişkeni yönünden eğitim düzeyleri farklı grupların ortalamaları karşılaştırılıp ortalamalar arasında fark olup olmadığı gözlemlenmiştir. Bu testte temizlik işçileri eğitim seviyelerine göre iki gruba ayrılarak incelenmiştir ve sonuçlar Tablo 1 'de gösterilmiştir.

Tablo 1. Eğitim seviyeleri yönünden tehlike etmenleriyle karşılaşma sıklığı verileri

\begin{tabular}{|c|c|c|c|}
\hline & \multicolumn{3}{|c|}{$\begin{array}{c}\text { Tehlike Etmenleriyle Karşılaşma } \\
\text { Sıklığı Skoru }\end{array}$} \\
\hline Eğitim Düzeyi & $\mathbf{N}$ & $\begin{array}{l}\text { Ortalama } \\
(\mathbf{X})\end{array}$ & $\begin{array}{c}\text { Standart sapma } \\
\text { (S) }\end{array}$ \\
\hline İlkokul & 35 & 30 & 2,5 \\
\hline $\begin{array}{l}\text { Ortaokul, lise ve } \\
\text { üniversite }\end{array}$ & 32 & 26,5 & 2,75 \\
\hline
\end{tabular}

Tablo 1'de eğitim düzeyi, ilkokul ve ortaokul, lise ve üniversite olarak iki kategoriye ayrılmış anket verileri ile hesaplanan standart sapma görülmektedir. Anket verilerine göre 35 kişi ilkokul, geri kalan 32 kişi ise ortaokul, lise veya üniversite mezunudur. Tablo 2'de yapılan varyans analizi değerleri verilmiştir.

Tablo 2. Eğitim seviyelerine göre varyans analiz sonuçları

\begin{tabular}{|l|l|}
\hline$F_{\text {hesap }}$ & 1,21 \\
\hline$F_{\text {tablo }}$ & 1,81 \\
\hline
\end{tabular}

$F_{\text {hesap }}$ değeri $F_{\text {tablo }}$ değerinden küçük olduğundan dolayı varyansların homojen olduğu kararına varılır. Hipotezlerin belirlenmesi için aşağıda bulunan Tablo 3 kullanılmıştır.

Tablo 3. Eğitim seviyelerine göre hipotez test sonuçları

\begin{tabular}{|c|c|}
\hline$X_{1}$ & 30 \\
\hline$X_{2}$ & 26,5 \\
\hline$S_{0}$ & 6,54 \\
\hline$t_{\text {hesap }}$ & 2,19 \\
\hline$t_{\text {tablo }}$ & 1,99 \\
\hline
\end{tabular}

$t_{\text {hesap }}$ değeri $t_{\text {tablo }}$ değerinden büyük olduğu için $H_{0}$ hipotezi reddedilir ve ortalamalar arasında fark olduğu kabul edilir. Uygulanan bu teste göre eğitim düzeyinin tehlike etmenleriyle karşılaşmada etkisinin olduğu sonucuna varılmıştır. Eğitim düzeyi azaldıkça tehlike etmenleriyle karşılaşma durumu artıyor söyleminde bulunulabilir. Bunun sebebi eğitim düzeyi yüksek olan bireyin aldığı eğitimden dolayı iş bilincinin daha fazla olması olabilir.

2. Yenimahalle Belediyesi temizlik işçilerine uygulanan anket sonucuna göre tehlike etmenleriyle karşılaşma sıklığı skoru değişkeni yönünden yaşları farklı grupların ortalamaları karşılaştırılıp ortalamalar arasında fark olup olmadığı gözlemlenmiştir. $\mathrm{Bu}$ testte temizlik işçileri yaşlarına göre iki gruba ayrılarak 
incelenmiştir ve ortaya çıkan sonuç Tablo 4'de verilmiştir.

Tablo 4. Yaş grupları yönünden tehlike etmenleriyle

\begin{tabular}{|c|c|c|c|}
\hline & \multicolumn{3}{|c|}{ karşılaşma sıklığı verileri } \\
\hline & \multicolumn{3}{|c|}{$\begin{array}{c}\text { Tehlike Etmenleriyle Karşılaşma } \\
\text { Sıklığı Skoru }\end{array}$} \\
\hline Yaş & $\mathbf{N}$ & $\begin{array}{l}\text { Ortalama } \\
(\mathbf{X})\end{array}$ & $\begin{array}{c}\text { Standart sapma } \\
\text { (S) }\end{array}$ \\
\hline $18-40$ & 21 & 18,5 & 1,25 \\
\hline $40+$ & 38 & 32 & 3 \\
\hline
\end{tabular}

Tablo 4'de yaş grupları, 18-40 ve 40 yaş ve üzeri olarak iki kategoriye ayrılmış anket verileri ile Excel'de hesaplanan standart sapmalar görülmektedir. Anket verilerine göre 21 kişi 18-40 yaş aralığında, 38 kişi ise 40 yaş ve üzeri yaşındadır. Bu sonuçlara göre varyans analizi yapılmıştır (Tablo 5)

Tablo 5. Yaş gruplarına göre varyans analiz sonuçları

\begin{tabular}{|c|c|}
\hline$F_{\text {hesap }}$ & 5,76 \\
\hline$F_{\text {tablo }}$ & 1,86 \\
\hline
\end{tabular}

$F_{\text {hesap }}$ değeri $F_{\text {tablo }}$ değerinden büyük olduğundan dolayı varyansların homojen olmadığı kararına varılır. Hipotezlerin belirlenmesi için kullanılan değerler Tablo 6'da yer almaktadır.

Tablo 6. Yaş gruplarına göre hipotez test sonuçları

\begin{tabular}{|c|c|}
\hline$X_{1}$ & 18,5 \\
\hline$X_{2}$ & 32 \\
\hline$S_{0}$ & 2,04 \\
\hline$t_{\text {hesap }}$ & $-24,30$ \\
\hline$t_{\text {tablo }}$ & 2,00 \\
\hline
\end{tabular}

$t_{\text {hesap }}$ değeri mutlak formülü içerisinde $t_{\text {tablo }}$ değerinden büyük olduğu için $H_{\circ}$ hipotezi reddedilir ve ortalamalar arasında fark olduğu kabul edilir. Uygulanan bu teste göre yaş farklılıklarının tehlike etmenleriyle karşılaşmada etkisinin olduğu sonucuna varılmıştır. Yaşça daha büyük olanların tehlike etmenleriyle karşılaşma durumunun daha yüksek olduğu gözlemlenmiştir. Bunun başlıca sebeplerinden biri yaş ilerledikçe bireyin iş başındaki rahatlı̆̆ı, bir diğer sebebi ise ileri yaşlardaki çalışanların verilen eğitimlere yeterli dikkati verememiş olması olduğu düşünülmektedir.

3. Yenimahalle Belediyesi temizlik işçilerine uygulanan anket sonucuna göre tehlike etmenleriyle karşılaşma sıklığı skoru değişkeni yönünden çalışma süreleri farklı grupların ortalamaları karşılaştırılıp ortalamalar arasında fark olup olmadığı gözlemlenmiştir. Bu testte temizlik işçileri çalışma sürelerine göre iki gruba ayrılarak incelenmiş ve sonuçlar Tablo 7 'de ortaya konmuştur.
Tablo 7. Çalışma süreleri yönünden tehlike etmenleriyle karşılaşma sıklığı verileri

\begin{tabular}{|c|c|c|c|}
\cline { 2 - 4 } \multicolumn{1}{c|}{} & \multicolumn{3}{c|}{$\begin{array}{c}\text { Tehlike Etmenleriyle Karşılaşma } \\
\text { Sıklı̆̆ Skoru }\end{array}$} \\
\hline $\begin{array}{c}\text { Çalışma } \\
\text { Süreleri }\end{array}$ & $\mathbf{N}$ & $\begin{array}{c}\text { Ortalama } \\
(\mathbf{X})\end{array}$ & $\begin{array}{c}\text { Standart sapma } \\
(\mathbf{S})\end{array}$ \\
\hline $0-5 \mathrm{Y}_{11}$ & 26 & 22,5 & 1,75 \\
\hline 5 Y1l+ & 25 & 22 & 1,5 \\
\hline
\end{tabular}

Tablo 7'de çalışma süreleri, 0-5 yıl ve 5 y1l ve üzeri olarak iki kategoriye ayrılmış anket verileri ile Excel'de hesaplanan standart sapmalar verilmiştir. Ankete göre 26 kişinin çalışma süresi $0-5$ yıl arasında olup 25 kişinin ise 5 yıl ve üzeridir. Buna göre yapılan varyans analizi Tablo 8'de yer almaktadır.

Tablo 8. Çalışma sürelerine göre varyans analiz sonuçları

\begin{tabular}{|l|l|}
\hline$F_{\text {hesap }}$ & 1,36 \\
\hline$F_{\text {tablo }}$ & 1,97 \\
\hline
\end{tabular}

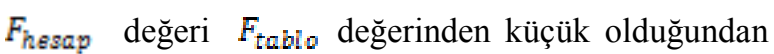
dolayı varyansların homojen olduğu kararına varılır. Hipotezlerin belirlenmesi için Tablo 9 kullanılmıştır.

Tablo 9. Çalışma sürelerine göre hipotez test sonuçları

\begin{tabular}{|c|c|}
\hline$X_{1}$ & 22,5 \\
\hline$X_{2}$ & 22 \\
\hline$S_{0}$ & 9,85 \\
\hline$t_{\text {hesap }}$ & 0,18 \\
\hline$t_{\text {tablo }}$ & 2,01 \\
\hline
\end{tabular}

$t_{\text {hesap }}$ değeri $t_{\text {tablo }}$ değerinden küçük olduğu için $H_{\text {o }}$ hipotezi ve ortalamalar arasında fark olmadığı kabul edilir. Uygulanan bu testten çıkarılan sonuca göre çalışma süresinin fazlalığının veya azlığının tehlike etmenleriyle karşılaşmada bir etkisinin olmadığı görülmüştür.

4. Yenimahalle Belediyesi temizlik işçilerine uygulanan anket sonucuna göre tehlike etmenleriyle karşılaşma sıklığı skoru değişkeni yönünden yaralanma ve / veya hastalık geçirip geçirmeme durumundan farklı grupların ortalamaları karşılaştırılıp ortalamalar arasında fark olup olmadığı gözlemlenmiştir. Bu testte temizlik işçileri yaralanma ve/veya hastalık geçirip geçirmeme durumlarına göre iki gruba ayrılarak incelenmiş ve sonuçlar Tablo 10 'da verilmiştir. 
Tablo 10. Yaralanma ve/veya hastalık geçirip geçirmemeleri yönünden tehlike etmenleriyle karşılaşma sıklığ 1 verileri

\begin{tabular}{|c|c|c|c|}
\cline { 2 - 4 } \multicolumn{1}{c|}{} & \multicolumn{3}{c|}{ Tehlike Etmenleriyle Karşılaşma } \\
\multicolumn{1}{c|}{ Sıklığı Skoru } \\
\hline $\begin{array}{c}\text { Yaralanma ve/veya } \\
\text { Hastalık Durumlarına } \\
\text { Göre }\end{array}$ & $\mathbf{N}$ & $\begin{array}{c}\text { Ortalama } \\
(\mathbf{X})\end{array}$ & $\begin{array}{c}\text { Standart } \\
\text { Sapma (S) }\end{array}$ \\
\hline $\begin{array}{c}\text { Yaralanma ve/veya } \\
\text { Hastalık Geçirenler }\end{array}$ & 27 & 22,5 & 2,25 \\
\hline $\begin{array}{c}\text { Yaralanma ve/veya } \\
\text { Hastalık Geçirmeyenler }\end{array}$ & 40 & 34 & 3 \\
\hline
\end{tabular}

Tablo 10'da yaralanma ve/veya hastalık geçirip geçirmeme durumlarına göre iki gruba ayrılmış olan çalışanların anket verileri ile Excel'de hesaplanmış standart sapmalar verilmiştir. Anket verilerine göre yaralanma ve/veya hastalık geçirenlerin sayısı 27 olup yaralanma ve/veya hastalık geçirmeyenlerin sayısı 40 kişidir. Yapılan varyans analizi Tablo 11'de gösterilmektedir.

Tablo 11. Yaralanma ve/veya hastalık geçirip geçirmeme durumlarına göre varyans analiz sonuçları

\begin{tabular}{|c|c|}
\hline$F_{\text {hesap }}$ & 1,77 \\
\hline$F_{\text {tablo }}$ & 1,78 \\
\hline
\end{tabular}

$F_{\text {hesap }}$ değeri $F_{\text {tablo }}$ değerinden küçük olduğundan dolayı varyansların homojen olduğu kararına varılır. Hipotezlerin belirlenmesi için Tablo 12 kullanılmıştır.

Tablo 12. Yaralanma ve/veya hastalık geçirip geçirmeme durumlarına göre hipotez test sonuçları

\begin{tabular}{|c|c|}
\hline$X_{1}$ & 22,5 \\
\hline$X_{2}$ & 34 \\
\hline$S_{0}$ & 16,87 \\
\hline$t_{\text {hesap }}$ & $-2,74$ \\
\hline$t_{\text {tablo }}$ & 1,99 \\
\hline
\end{tabular}

$t_{\text {hesap }}$ değeri mutlak değer formülü içerisinde $t_{\text {tablo }}$ değerinden büyük olduğu için $H_{\text {o }}$ hipotezi reddedilir ve ortalamalar arasında fark olduğu kabul edilir. Uygulanan bu testten çıkarılan sonuca göre daha önceden yaralanma ve/veya hastalık geçirmemiş olanların daha önceden yaralanma ve/veya hastalık geçirmiş olanlara göre tehlike etmenleriyle karşılaşmasının daha fazla olduğu görülmüştür. Bunun başlica sebebi önceden en az bir kere yaralanma ve/veya hastalık geçirmiş olanların iş ile ilgili yeterli tecrübeyi edinmiş olup yapılan iş hakkında daha da bilinçlenmesi olduğu düşünülmektedir.

5. Yenimahalle Belediyesi temizlik işçilerine uygulanan anket sonucuna göre yaralanma ve/veya hastalık geçirme sıklığg skoru değişkeni yönünden işe başlamadan önce teknik eğitimleri almış ve almamış olan işçiler şeklinde farklı grupların ortalamaları karşılaştırılıp ortalamalar arasında fark olup olmadığı gözlemlenmiştir. $\mathrm{Bu}$ testte temizlik işçileri işe başlamadan önce teknik eğitim alan ve almayan işçiler olmak üzere iki gruba ayrılarak incelenmiştir ve değerler Tablo 13'de verilmiştir.

Tablo 13. İşçilerin işe başlamadan önce teknik eğitim alıp almama durumlarına göre yaralanma ve/veya hastalık geçirme sıklığ 1 verileri

Yaralanma ve/veya

\begin{tabular}{|c|c|c|c|}
\hline & \multicolumn{3}{|c|}{$\begin{array}{c}\text { Yaralanma ve/veya } \\
\text { Hastalanma Sıklığı Skoru }\end{array}$} \\
\hline $\begin{array}{c}\text { Teknik eğitim alıp } \\
\text { almama durumlarına } \\
\text { göre }\end{array}$ & $\mathbf{N}$ & $\begin{array}{c}\text { Ortalama } \\
(\mathrm{X})\end{array}$ & $\begin{array}{l}\text { Standart } \\
\text { sapma } \\
(\mathrm{S})\end{array}$ \\
\hline $\begin{array}{l}\text { Teknik eğitim almış } \\
\text { olanlar }\end{array}$ & 48 & 35,5 & 6,25 \\
\hline $\begin{array}{c}\text { Teknik eğitim almamış } \\
\text { olanlar }\end{array}$ & 19 & 11 & 4 \\
\hline
\end{tabular}

Tablo 13'de teknik eğitim alıp almama durumlarına göre iki gruba ayrılmış çalışanların anket verileri ile Excel'de hesaplanmış standart sapmalar verilmiştir. Anket verilerine göre teknik eğitim almış olan kişi sayısı 48 olup teknik eğitim almamış olan kişi sayısı 19 dur. Yapılan varyans analizi sonuçları Tablo 14'de gösterilmektedir.

Tablo 14. İşçilerin işe başlamadan önce teknik eğitim alıp almama durumlarına göre varyans analiz sonuçları

\begin{tabular}{|l|l|}
\hline$F_{\text {hesap }}$ & 2,44 \\
\hline$F_{\text {tablo }}$ & 2,04 \\
\hline
\end{tabular}

$F_{\text {hesap }}$ değeri $F_{\text {tablo }}$ değerinden büyük olduğundan dolayı varyansların homojen olmadığı kararına varılır. Hipotezlerin belirlenmesi için Tablo 15 kullanılmıştır.

Tablo 15. İşçilerin işe başlamadan önce teknik eğitim alıp almama durumlarına göre hipotez test sonuçları

\begin{tabular}{|c|c|}
\hline$X_{1}$ & 35,5 \\
\hline$X_{2}$ & 11 \\
\hline$S_{0}$ & 0,71 \\
\hline$t_{\text {hesap }}$ & 127,49 \\
\hline$t_{\text {tablo }}$ & 1,99 \\
\hline
\end{tabular}

$t_{\text {hesap }}$ değeri, $t_{\text {tablo }}$ değerinden büyük olduğu için $H_{0}$ hipotezi reddedilir ve ortalamalar arasında fark olduğu kabul edilir. Uygulanan bu testten çıkarılan sonuca göre önceden teknik eğitim almış olanları yaralanma ve/veya hastalanma sıklığının teknik eğitim almamış olanlara göre daha fazla olduğu görülmüştür. Bu durumdan çıkartılacak tek sonuç iş kazalarının büyük bir kısmının insan kaynaklı olduğudur. Her ne kadar iş ile ilgili teknik eğitimler verilip kişisel koruyucu donanım ekipmanlarının öneminden bahsedilse de çalışanların dikkatsizliği ve bilinçsizliğinin iş 
kazalarına yol açtı̆̆g düşünülmektedir.

6. Yenimahalle Belediyesi temizlik işçilerine uygulanan anket sonucuna göre yaralanma ve/veya hastalık geçirme sıklığı skoru değişkeni yönünden iş sırasında gerekli güvenlik önlemlerinin alınıyor olması ve alınmıyor olması şeklinde farklı grupların ortalamaları karşılaştırılıp ortalamalar arasında fark olup olmadığı gözlemlenmiştir. Bu test iş sırasında işçiler için gerekli güvenlik önlemlerinin alınıyor olması ve alınmıyor olması şeklinde iki gruba ayrılarak incelenmiş ve değerler Tablo 16 'da verilmiştir

Tablo 16. İşçiler için gerekli güvenlik önlemlerinin alınıyor olması ve alınmıyor olması durumlarına göre yaralanma ve/veya hastalık geçirme sıklığı verileri

\begin{tabular}{|c|c|c|c|}
\cline { 2 - 4 } \multicolumn{1}{c|}{} & \multicolumn{3}{c|}{ Yaralanma ve/veya Hastalanma } \\
Sıklığı Skoru \\
\hline $\begin{array}{c}\text { Ö̈n̈lemlerinin alınıp } \\
\text { alınmaması } \\
\text { durumuna göre }\end{array}$ & $\mathbf{N}$ & $\begin{array}{c}\text { Ortalama } \\
(\mathbf{X})\end{array}$ & $\begin{array}{c}\text { Standart } \\
\text { sapma } \\
(\mathbf{S})\end{array}$ \\
\hline $\begin{array}{c}\text { Güvenlik önlemleri } \\
\text { alınıyor }\end{array}$ & 43 & 29,5 & 6,75 \\
\hline $\begin{array}{c}\text { Güvenlik önlemleri } \\
\text { alınmıyor }\end{array}$ & 24 & 16,5 & 3,75 \\
\hline
\end{tabular}

Tablo 16'da güvenlik önlemlerinin alınıp alınmaması durumlarına göre iki gruba ayrılmış çalışanların anket verileri ile Excel'de hesaplanmış standart sapmalar verilmiştir. Anket verilerine göre güvenlik önlemlerinin alınıyor oluğunu iddia eden kişi sayısı 43 olup, güvenlik önlemlerinin alınmıyor olduğunu iddia eden kişi sayısı 24 kişidir. Yapılan varyans analizi sonuçları Tablo 17'de gösterilmektedir.

Tablo 17. İşçiler için gerekli güvenlik önlemlerinin alınıyor ve alınmıyor olması durumlarına göre varyans analiz sonuçları

\begin{tabular}{|c|c|}
\hline$F_{\text {hesap }}$ & 3,24 \\
\hline$F_{\text {tablo }}$ & 1,91 \\
\hline
\end{tabular}

$F_{\text {hesap }}$ değeri $F_{\text {tablo }}$ değerinden büyük olduğundan dolayı varyansların homojen olmadığı kararına varılır. Hipotezlerin belirlenmesi için Tablo 18 kullanılmıştır.

Tablo 18. İşçiler için gerekli güvenlik önlemlerinin alınıyor ve alınmıyor olması durumlarına göre hipotez test sonuçları

\begin{tabular}{|c|c|}
\hline$X_{1}$ & 29,5 \\
\hline$X_{2}$ & 16,5 \\
\hline$S_{0}$ & 5,87 \\
\hline$t_{\text {hesap }}$ & 8,70 \\
\hline$t_{\text {tablo }}$ & 1,99 \\
\hline
\end{tabular}

$t_{\text {hesap }}$ değeri $t_{\text {tablo değerinden büyük olduğu için } H_{0}}$ hipotezi reddedilir ve ortalamalar arasında fark olduğu kabul edilir. Uygulanan bu testten çıkarılan sonuca göre güvenlik önlemlerinin alınıyor olduğunu iddia edenlerin güvenlik önlemlerinin alınmıyor olduğunu iddia edenlere göre daha fazla yaralanma ve/veya hastalanma geçirdikleri görülmektedir. Yine bu durumdan yapılacak en büyük çıkarım iş kazalarının önemli kısmının insan kaynaklı olduğudur. Her ne kadar iş ile ilgili gerekli ve yeterli güvenlik önlemleri alınıyor olsa çalışanların dikkatsizliği ve bilinçsizliğinin iş kazalarına yol açabilmektedir.

Ankara'nın ikinci en büyük belediyesi olan Yenimahalle Belediyesi temizlik işleri bünyesinde yapılmış olan anket çalışması sonuçlarına göre kurulan hipotez test verileri ışığında evsel katı atık toplama ve taşıma işkolunda çalışan işçilerde çalışma sürelerine göre tehlike etmenleriyle karşılaşma sıklığı yönündeki puanlamalarda fark olmadığı gözlemlenmiştir. Çalışma süresi dışındaki eğitim düzeyleri, yaş grupları, yaralanma ve/veya hastalık geçirme durumları, teknik eğitim almış olmak ve almamış olmak durumları ve güvenlik önlemlerinin alınıyor ve alınmıyor olması durumlarına göre tehlike etmenleriyle karşılaşma sıklığı ölçeğindeki puanlamalarda fark olduğu gözlemlenmiştir. Veriler incelendiğinde, eğitim düzeyi ilkokul olan çalışanların, 40 yaş ve üzeri çalışanların ve çalışma süresi 5 yıldan daha az olan çalışanların tehlike etmenleriyle karşılaşma sıklığı skoru ortalamalarının daha fazla olduğu gözlemlenmiştir. Dolayısıyla çalışanların eğitim düzeyi düştükçe, yaşları ilerledikçe ve çalışma sürelerinden dolayı işe alışma süreçleri uzadıkça çalışma ortamındaki risk ve tehlikelerle daha fazla karşılaştığı ve iş güvenliği bilincinin daha az olduğu görülmüştür. Anket sonuçlarına göre beklenilenin aksine teknik eğitim almış olanlar ve güvenlik önlemlerinin alınıyor olduğunu belirten çalışanların tehlike etmenleriyle karşılaşma sıklığı ortalaması daha yüksek çıkmıştır.

Anket çalışması kapsamında, çalışanlara yöneltilen tehlike etmenleriyle karşılaşma sıklığı sorusunda gürültü en çok maruz kalınan tehlike etmeni olmuştur. Gürültüyü sırasıyla egzoz gazı, ağır yük kaldırma, haşere ve hayvanla karşılaşma, kesici ve/veya delici alet ve titreşime maruz kalma izlemektedir. Ankette yöneltilen bir diğer soru olan geçirilen yaralanma ve hastalıklar sorusunda kesilme ve/veya delinme yaralanmaları çalışanlar tarafından en çok karşılaşılan yaralanmadir. Kesilme ve/veya delinme yaralanmalarını sirasıyla ezilme ve incinme, cilt ve alerjik hastalıklar, belirtilmeyen diğer yaralanma ve hastalıklar, solunum hastalıkları ve kırık ve/veya çatlak yaralanmaları izlemektedir.

Evsel katı atık toplama ve taşıma iş kolunda çalışanlar sıklıkla çeşitli yaralanma ve kazalarla karşılaşmaktadır. Türkiye'de, dünyada kullanılmakta olan vakum teknolojisiyle çöp toplama ve tam otomatik çöp toplama sistemlerine geçen bir belediye henüz 
bulunmamaktadır. Ankara'nın iki en büyük belediyesi olan Yenimahalle ve Çankaya Belediyelerince uygulanan yeraltı çöp toplama sistemi (daldırmalı çöp konteyner sistemi) Ankara'nın diğer ilçelerinde de yaygınlaşmaya başlamıştır. Kullanılan bu sistemin en büyük faydalarından biri işçilerin konteynerleri kaldırma, itme ve çekme gibi işler yapmayacağından dolayı ağır yük kaldırma tehlikesi ortadan kalkmasıdır. Diğer bir faydası ise işçilerin çöpe teması olmaması sonucunda kesilme ve delinme, solunum ve enfeksiyon hastalıkları tehlikeleri ortadan kalkacaktır. Yapılan bu araştırma sonucunda çöp toplama iş kolunda çalışanların en sık karşılaştığı yaralanma çeşitleri sirasıly kesilme ve delinme, trafik kazaları ve solunum ve enfeksiyon hastalıkları olduğu ortaya çıkmıştır. Amerika Birleşik Devletleri Florida örneğinde ise bu durum ezilme ve incinme, kırık ve çatlak şeklindedir [1].

\section{SONUÇLAR}

$\mathrm{Bu}$ çalışma kapsamında evsel katı atık toplama ve taşıma kolunda çalışanların iş sağlığı ve güvenliği koşulları değerlendirilmiş olup gelecekteki çalışmalara ve iyileştirmelere 1 şık tutulması amaçlanmıştır. Yenimahalle Belediyesinin bu işkolundaki çalışanlara uyguladığı anket verilerine göre yapılan hipotez testleri sonucunda eğitim düzeyi düşük olan ve 40 yaş ve üzeri olan çalışanların tehlike etmenleriyle karşılaşma sıklığ daha fazla olduğu tespit edilmiştir. Belirtilen bu konular üzerine yoğunlaşılmalı ve gerekli eğitimler verilerek konuyu çözmeye yönelik farkındalık yaratılması gerekmektedir. Saha çalışması kapsamında, gürültü ve kesici/delici aletlerle karşılaşma açısından önlem alınması gerektiği görülmüştür.

Dünyada kullanılan çöp toplama ve taşıma sistemlerinin Türkiye'de de kullanılması evsel katı atık toplama ve taşıma işkolunda çalışanların çalışma koşullarının iyileştirilmesi açısından gereklidir. Teknolojideki yenilikler insan gücünü ortadan kaldırdığı gibi fiziksel, kimyasal, biyolojik ve ergonomik risk etmenleriyle de karşı karşıya gelmemiş olacaklardır. Türkiye'de çöp toplama sistemlerindeki yeni teknolojiler maliyetleri açısından çok fazla uygulanamasa bile en azından daldırmalı çöp konteyneri sisteminin yaygınlaştırılması amaçlanmalıdır. Genel olarak bütün yeni ve gelişmiş uygulamaların yüksek maliyetleri olsa da, insan hayatının paha biçilemez olduğu gerçeği asla unutulmamalidir.

Son yıllarda ülkemizde iş sağlığı ve güvenliği bilincinin yayılması evsel katı atık toplama ve taşıma işkoluna da önemli katkılar sağlamaktadır. Belediyeler, gelişen iş sağlığ 1 ve güvenliği bilinciyle birlikte gelişen teknolojiyi kullanmaya başlamış olsalar da bu yeterli seviyede görülmemektedir.

\section{KAYNAKLAR}

[1] Yaşaroğlu CB. (2014) Evsel Katı Atık Toplama ve Taşıma İşkolunda Çalışanların İş Sağlığı ve Güvenliği Koşullarının İyileştirilmesi. Uzmanlık Tezi, Ankara.

[2] Waste Collection Solutions, http://www.envacgroup.com/products and services/o ur products/movac-the-3rdgeneration-mobilevacuum-system/technical facts_movac $\underline{(05.11 .2019)}$

[3] Hidalgo D., Juaristi J.L., Martín-Marroquín J.M., Corona F. (2018) Sustainable Vacuum Waste Collection Systems in Areas of Difficult Access. Spain.

[4] İki Ortalama Arasındaki Farkın Önemlilik Testi, https://docplayer.biz.tr/9878809-Iki-ortalamaarasindaki-farkin-onemlilik-testi.html, (11.10.2019) 